\title{
Effectiveness Guided Discovery Learning Model With Macromedia Flash Animation Toward Misconception Decreation
}

\author{
Apryza Ryzchy Pratama Putra Negara Sugiyanto ${ }^{1}$, Ixora Sartika Mercuriani ${ }^{2}$ \\ \{apryzaryzchy.2017@student.uny.ac.id ${ }^{1}$, ixomerc@uny.ac.id ${ }^{2}$ \} \\ ${ }^{1}$ Postgraduate Biology Education, Universitas Negeri Yogyakarta, Jalan Colombo No.1, Indonesia \\ ${ }^{2}$ Biology Education, Universitas Negeri Yogyakarta, Jalan Colombo No.1, Indonesia
}

\begin{abstract}
This study aimed to understand the effectiveness of Guided Discovery Learning model with macro media flash animation to decrease misconception. This study is a quantitative research using quasi-experimental design with the control group and experimental group as the sample. The sampling technique employed was cluster random sampling. Collecting data used four-tier test. The data analysis result based on the independent sample t-test showed value $0,00<0,05$. The result of the $\mathrm{N}$-Gain score analysis in experiment group showed 0,49 and the $\mathrm{N}-$ Gain score in the control group is 0,30 , both of the scores were in the low category. It can be concluded that learning activity using guided discovery learning model with macro media flash animation can be better to decrease student misconception, although of both of learning model in experiment and control group included to the scientific approach. Macromedia flash animation used in the experiment class can support learning process and understanding concept.
\end{abstract}

Keywords: Decreation Misconception, Guided Discovery Learning, Macromedia Flash Animation

\section{Introduction}

Biology is part of the science of natural knowledge that studies scientific concepts about the life of living things with all their interactions. Biology has several material concepts deemed difficult to understand by students such as the material of the coordination system which includes the nerve system, the immune system, and sensory organs, of these three materials the nervous system is one of the materials considered difficult for students to understand because it cannot be observed directly. The concepts in the material are important to learn because there is important information that studies the structure, shape, and coordination of the functions of the human nervous system. To master the learning material that the students should be able to understand the concept - the concept contained in the material human well-coordinated system. The process of mastering the material is certainly not easy to do because it requires a suitable model so that the material can be understood.

Changes in the current curriculum affect the learning process that is applied when learning. The curriculum used is the 2013 curriculum (K13) which is expected to improve the quality of student learning in schools. K13 learning is conducted by centering on students who are required to be active in finding information on learning material that is learned (discovery learning) with a scientific approach based learning model. Searching for information carried 
out by students often do not have problems in the learning process. A common problem encountered when learning is understanding the concept of the material being studied students, so it can happen in understanding the material misconception that. The misconception is a wrong concept when understood or a different conception with the scientific agreement [14]. Misconceptions occur when students are trying to understand or form knowledge by translating what they have just learned or new experiences in the form of initial conceptions $[8]$.

The misconception has been widely researched in the field of science. Misconceptions in learning biology, among others, are related to the concept of genetics [9], excretion [11], ecosystems [6]. Misconceptions are possible in other concepts. Difficulties experienced by students can come from unfamiliar terms in biology that have not been accepted and mastered, as well as the level of complexity of a concept due to the complexity of the information or characteristics that shape the concept [8]. Based on the results of interviews conducted at SMAN 1 Pundong stated that in the coordination system material taught is difficult for students to understand because the material is quite complicated and requires a good understanding to be able to learn the material and in the learning process often teachers find students who misconception (misconception) regarding the contents of the material.

The guided discovery learning model is a learning model that requires students to learn actively by providing opportunities for students to find their own learning experiences. Model guided discovery learning is a learning model discovery (discovery) and is essentially the same as the inquiry approach or an advanced stage of inquiry [3]. This learning model has four formats in the stages of learning, namely 1) receiving direction for learning, 2) searching, finding, and creating, 3) giving arguments and solutions, and 4) acting on what is learned. The four stages are based on how students construct the concept information they get [3]. As a reinforcement of the information construction obtained, the learning process is integrated with interactive video animation media so students better understand the material being studied. [13] states that learning using video is included in both categories. Video is an audio-visual media that can clarify objects and events as they are. While the animation is a picture of two dimention as if moving. Macromedia Flash is a media device that can help visualize abstract concepts. [1] shows that learning using flash animation can reduce student misconceptions by $50.95 \%$ and has an effect size of 1.58 with a high category.

\section{Method}

This type of research in this study is quantitative research with quasi-experimental methods (quasi-experiment). This study uses a nonequivalent control group design. This design uses the experimental group and the control group. In the experimental group, the treatment by providing guided discovery learning models assisted by macro flash media, while the control group treated with the 5M model.

The study was conducted at SMA Negeri 1 Pundong, Bantul Regency, Yogyakarta in April 2019. The research population used was the population of class XI IPA students at SMA Negeri 1 Pundong. The research sample used is students of class XI Science 3 as the experimental group and class XI Science 2 as a control group. Each class consists of 32 students. The research sample was taken using cluster random sampling technique.

The instrument used in the study was a four-tier misconception based diagnostic test instrument namely vibration conceptual change inventory (VCCI). The test instrument was arranged to identify the existence of misconceptions in students on the material of the human 
nervous system. The misconception identification instrument refers to the instrument that has been developed from a three-tier based measurement model [4].

Pretest and posttest results obtained were then analyzed parametric prerequisite tests in the form of normality and homogeneity tests with SPSS 17. Normality tests were used to determine whether the population data were normally distributed or not, whereas for homogeneity tests used to determine variants of the population used the same or not. The data obtained is analyzed fulfills the parametric requirements then it will be continued with the hypothesis test using the independent sample t-test.

Data were taken using pre-test and posttest tests calculated an increase in understanding obtained by students using N-Gain to obtain information on the effectiveness of the learning model used for both treatment groups. Following the N-Gain formula used according to [5], namely:

$$
\langle g\rangle=\frac{\%\left\langle s_{f}\right\rangle-\%\left\langle s_{i}\right\rangle}{\%\left\langle s_{\max }\right\rangle-\%\left\langle s_{i}\right\rangle}
$$

The results of this calculation are then interpreted based on the criteria for obtaining an NGain score as in table 1. below :

Tabel 1. N- Gain Qualitative Scores Criteria Range

\begin{tabular}{cc}
\hline Batasan & Kategori \\
\hline $\mathrm{g}>0,7$ & High \\
$0,3<\mathrm{g} \leq 0,7$ & Medium \\
$\mathrm{G} \leq 0,3$ & Low \\
\hline
\end{tabular}

\section{Results}

Based on the results of the study, obtained the results of descriptive analysis of the level of misconception students have through the results of the pre-test and post-test scores in the experimental and control groups, the data obtained are presented in table 2. Based on these data it can be seen that the pre -average scores the experimental group test and the control class are 56.25 and 50.83. The data has a difference of a value of 5.42 although the initial value of the experimental group was higher than the control group the data is still in the initial understanding of the range of values the same between the experimental group and the control group before treatment is given. After treatment was given to the two groups, the data obtained showed differences in the mean values between the experimental class and the control class. Data on the average value obtained after treatment was given showed that there was an increase in both treatments, namely in the experimental group with a value of 82.29 and in the control group 68.96 .

Tabel 2. Comparative Data of Experiment Group and Control Group Values

\begin{tabular}{lll}
\multirow{3}{*}{ Description } & \multicolumn{2}{c}{ Group } \\
\cline { 2 - 3 } & $\begin{array}{l}\text { Experiments ( Guided } \\
\text { Discovery Learning Model }+\end{array}$ & Control (5M Model) \\
\hline
\end{tabular}




\begin{tabular}{lcccc}
\hline & \multicolumn{4}{l}{ Media Macro Flash ) } \\
\cline { 2 - 5 } & Pre-test & Post-test & Pre-test & Post-test \\
\hline Average & 56,25 & 82,29 & 50,83 & 68,96 \\
Maximum Value & 75 & 100 & 80 & 90 \\
Minimum Value & 35 & 65 & 10 & 35 \\
\hline
\end{tabular}

Based on the analysis of the results obtained in table 3. note that there are changes that occur after the treatment is given, as seen in table 3. The results in the experimental group show that there is a decrease in the number of students who experience misconceptions. Item 1 data items there are 4 students who experience misconceptions and decreased to 0 students, item items 2 there are 6 students decreased to 3 students, item items 3 there are 12 students decreased to 1 student, item items 4 there are 8 students decreased to 1 student, items Question 5 there are 19 students decreased to 18 students, Item 6 there are 10 students decreased to 5 students, Item 7 has 5 students decreased to 0 students, Item 8 has 17 students decreased to 5 students, Item 9 has 3 students decreased to 0 students, and item 10 questions there are 0 students increased to 1 student.

Whereas the change control group was shown by decreasing and increasing misconceptions. In item 1 there are 5 students decreased to 4 students, item 2 has 12 students decreased to 11 students, item 3 has 2 students became 2 students, item 4 has 10 students increased to 12 students, item 5 has 13 students decreased to 9 students, item 6 had 9 students increased to 13 students, item 7 had 7 students decreased to 2 students, item 8 had 14 students increased to 20 students, item 9 had 2 students increased to 3 students, and Item 10 there are 2 students decreased to 0 students.

Tabel 3. Number of Students Experiencing Experimental Group Misconceptions

\begin{tabular}{ccccc}
\hline & \multicolumn{4}{c}{$\begin{array}{c}\text { Number of Students experiencing } \\
\text { Misconceptions }\end{array}$} \\
\cline { 2 - 5 } Question & \multicolumn{3}{c}{ Eksperimen } & \multicolumn{2}{c}{ Control } \\
\cline { 2 - 5 } & Pretest & Posttest & Pretest & Posttest \\
\hline 1 & 4 & 0 & 5 & 4 \\
2 & 6 & 3 & 12 & 11 \\
3 & 12 & 1 & 2 & 2 \\
4 & 8 & 1 & 10 & 12 \\
5 & 19 & 18 & 13 & 9 \\
6 & 10 & 5 & 9 & 13 \\
7 & 5 & 0 & 7 & 2 \\
8 & 17 & 5 & 14 & 20 \\
9 & 3 & 2 & 2 & 3 \\
10 & 0 & 1 & 2 & 0 \\
\hline
\end{tabular}


Based on the results of the homogeneous test analysis presented in table 4., the data show the significant value of posttest in the experimental class is 0.200 and in the control class is 0.66 . The significance value of the data in both classes shows a value greater than the value of $\alpha(0.05)$. This shows that the data in both classes are normally distributed.

Tabel 4. Normality Test Results

\begin{tabular}{cccc}
\hline No & Data & Sig & Concession \\
\hline 1 & Eksperimen & 0,200 & Normal \\
\hline 2 & Control & 0,066 & Normal \\
\hline
\end{tabular}

Based on the results of the homogeneity test analysis presented in Table 5., it shows that the posttest of the experimental group and the control group has a significance value greater than the $\alpha(0.05)$ value. The significance data shows the value of 0.112 . This shows the variation of values in the two groups, namely the experimental group and the control group was homogeneous.

Tabel 5. Hasil Homogeneity Test

\begin{tabular}{|c|c|c|c|}
\hline No & Data & Sig. & Concession \\
\hline 1 & Eksperimen & \multirow{2}{*}{0,112} & \multirow{2}{*}{ Homogen } \\
\hline 2 & Control & & \\
\hline
\end{tabular}

Based on the results of the independent sample t-test analysis in Table 5., the significance value obtained in the experimental and control groups is smaller than the $\alpha(0.05)$ value of 0.00. It shows that the $\mathrm{H}_{0}$ in decline is no significant difference between the value of the experimental class that uses the model of guided discovery learning -assisted media macro flash with the control group with 5M models.

Tabel 6. Test results are independent of sample t-test

\begin{tabular}{cccc}
\hline No & Data & Sig. & Conclusion \\
\hline 1 & Eksperimen & \multirow{2}{*}{0,00} & $\begin{array}{c}\text { There is a } \\
\text { difference }\end{array}$ \\
\hline 2 & Control & &
\end{tabular}

Based on the analysis of the N-Gain test in table 7., it shows that in the experimental group the $\mathrm{N}$-gain value is 0.49 . The score in the $\mathrm{N}$-Gain criteria is in the range of scores of $0.3 \leq \mathrm{g} \leq$ 0.7 meaning that in the criteria of being. While in the control group the N-Gain value was 0.30 . The score in the $\mathrm{N}$-Gain criteria is low which is in the range of $0.00 \leq \mathrm{g} \leq 0.3$.

Tabel 7. N-Gain Test Results

\begin{tabular}{ccccc}
\hline & \multicolumn{2}{c}{ Experiment Group } & \multicolumn{2}{c}{ Control class } \\
\cline { 2 - 5 } & Pre-test & Post-test & Pre-test & Posttest \\
\hline Average & 56,25 & 82,29 & 50,83 & 68,96 \\
N-Gain & \multicolumn{2}{c}{0,49} & \multicolumn{2}{c}{0,30} \\
Criteria & \multicolumn{2}{c}{ Medium } & \multicolumn{2}{c}{ Low } \\
\hline
\end{tabular}

\section{Discussion}


Learning done by applying guided discovery learning model assisted by Macro Flash Media is effective in reducing students' misconceptions on the nervous system material compared to the use of the $5 \mathrm{M}$ model.This is shown from the results of the independent sample t-test by obtaining a significance value smaller than $\alpha$ that is $0.00(<0.05)$. This value means that there are differences in the value of the results after learning with guided discovery learning models assisted by macro flash media with the value using the $5 \mathrm{M}$ model. These results can be seen in the average value after giving treatment to the two groups, namely, in the experimental group, the average obtained was 82.29 while in the control group the average value obtained was only 68.96 . Based on the N-Gain value obtained in the experimental group that is 0.49 with moderate criteria, while the results in the control group only obtained an NGain value that is 0.30 with a low category.

Guided discovery learning model macro media flash-assisted learning effectively in reducing misconceptions on the matter of the nervous system compared with $5 \mathrm{M}$ learning model because the model of guided discovery learning their lessons involving teachers and students are interacting. The guided discovery learning model is done by a method that combines learning with a teacher-centered teaching student-centered [3]. The guided discovery learning model provides opportunities for students to organize, process, and organize a given data so that in the process of finding students can use their ideas and understanding, the process is also guided by the teacher during the learning process.

At stages model of learning that can create learning situations that involve students to learn actively and independently when seeking information or theories and concepts learned so that students are better informed. Students who are actively learning to find information learned can stimulate students to construct the knowledge they have acquired. Providing an initial description of the information about the topic to be studied and discussed it will stimulate students to think actively and construct a description of the information. When constructing the initial information students are invited to discuss so students can imagine and develop the topics discussed. Furthermore, students conduct investigations by making direct observations according to instructions and suggestions given by the teacher. The results obtained from these observations are represented in written form and drawings so that the strengthening of the concept of learning topics obtained becomes stronger. The results of the concepts that have been obtained can be discussed again so that students get more accurate information and concepts.

Model guided discovery learning is also integrated with macro flash media in the learning process so that the provision of learning made becomes more interesting and increases student interest in learning. [10] learning by using video media has several advantages in seeing video programs together and different students can build common experiences to discuss an issue effectively or each student has a uniform understanding of the material. The giving of macro flash media is done at the beginning of learning when students construct the given initial knowledge. The use of animation in the learning process will give the impression of jealousy to students in learning, especially if there are animated images and colors that are displayed can improve student memory. [15] states the use of biology learning modules can improve motivation, response, activities and better learning outcomes. The use of animation media for learning can unite the conception of students in learning the abstract material so it can reduce misconceptions that occur in materials that are difficult to understand. The integration of animation media during the nervous system learning process allows students to understand in more detail the forms and processes that occur in the material. Students can see firsthand the process of the delivery of the impulse mechanism displayed in the animation, a form that clarifies the nervous system and the locations of the nervous system constituents. 
Whereas in the defense of the $5 \mathrm{M}$ model, the learning process carried out in the initial process is observing. Permendikbud number 81 a states teachers should open wide and varied opportunities for students to make observations through activities: seeing, listening, listening and reading (Kemdikbud, 2013) [7] . But sometimes in the process of observing students are reluctant or do not care when identifying (reading) about the topic being taught it is possible the lack of student motivation due to no trigger for students to be interested in observing the topic of the material being taught. This affects the student's questioning process because the quality of the questions students give is still low and sometimes irrelevant to the topic taught because the initial knowledge students have is inadequate. This is in line with the results of the study [2] which states that students sometimes feel ashamed when asking questions when they have difficulties and still lack confidence in communicating. Then in the ability to ask, students tend to experience confusion about what they will ask and most do not dare to ask. In the learning process when students do data collection the process requires more time. The process is balanced with the length of data processing that has been collected to become informative data. When the process of communicating information that students have compiled, some students do not dare to disclose their findings, this is evidenced by the nature of doubt that students have in conveying the information they get, then with students' uncertainty in the disclosure of information that has been arranged in such away. [2] states that when the process of communicating learning outcomes is still visible students who are busy themselves, do not pay attention, are busy themselves and when the question and answer process is done it is still rare for students to ask questions.

\section{Conclusions}

Guided discovery learning model assisted by macro flash media is effective in reducing misconceptions in class XI of SMA Negeri 1 Pundong on the material of the human nervous system. This result is evidenced by the decrease in misconceptions that occur after learning is done by doing a posttest. Analysis of the results obtained from the independent sample t-test with sig values. smaller than $\alpha(0.05)$ which is 0.00 . These results are also evidenced by the higher N-Gain value of the experimental group compared to the control group of 0.49 with medium criteria and 0.30 with low criteria.

\section{References}

[1] Andriana, E.: Remediasi Miskonsepsi Pembiasan Cahaya Pada Lensa Tipis Menggunakan Direct Instruction Berbantuan Animasi Flash Sma. Jurnal Pendidikan dan Pembelajaran. Vol 3. pp. 1-11 (2014)

[2] Anjarsari, E.: Faktor Permasalahan Pendekatan Saintifik 5M dalam Pembelajaran Matematika di SMA. vol. 1. Jurnal pendidikan matematika dan matematika. pp. 12-20 (2019)

[3] Carin, A. A.: Teaching Modern Science (7th ed.).Columbus: Macmillan Publishing, pp. 181 (1993)

[4] Fariyani, Q. Ani Rusilowati, sugiyanto.: Pengembangan Four-Tier Diagnostic Test untuk Mengungkap Miskonsepsi Fisika Siswa Kelas X. Jurnal of innovative science Education. Universitas negeri semarang. pp. 41-49 (2015)

[5] Hake, R. : Analyzing Change/Gain scores. (1999)

[6] Kaniraras, D.A. Karyanto, P. Nurmiyati, \& Kusumawati, L.: Penerapan E-module Berbasis Problem-Based Learning untuk Meningkatkan Kemampuan Berpikir Tingkat Tinggi dan Mengurangi Miskonsepsi pada Materi Ekosistem Siswa Kelas X Sains 1 SMA Negeri 2 
Karanganyar Tahun Pelajaran 2014/2015. Makalah Seminar Nasional XII Pendidikan Biologi FKIP UNS 2015. Surakarta: Universitas Negeri Sebelas Maret Surakarta. pp. 186-192 (2015)

[7] Kemdikbud.: Pendekatan Scientific (Ilmiah) dalam Pembelajaran. Pusbangprodik. Jakarta. (2013)

[8] National Science Teachers Association.: Buku Pedoman Guru Biologi Edisi ke-4. PT Grasindo (2013)

[9] Nusantari, E.: Analisis dan penyebab Miskonsepsi pada Materi Genetika Buku SMA Kelas XII. Bioedukasi vol. 4.: pp. 72-85 ( 2011)

[10] Primavera, I.R.C. \& Suwarna, I.P.: Pengaruh media audio-visual (video) terhadap hasil belajar siswa kelas XI pada konsep elastisitas. Prosiding. FITKUIN Syarif Hidayatullah. Pp.122-129 (2014)

[11] Rahmawati, Y., B.A. Prayitno, \& M. Indrowati.: Studi Komparasi Tingkat Miskonsepsi Siswa pada Pembelajaran Biologi melalui Model Pembelajaran Konstruktivisme Tipe Novick dan Konstruktivis-Kolaboratif. Makalah Semnas X Biologi FKIP UNS.Surakarta: Universitas Negeri Sebelas Maret Surakarta. pp. 1-7 (2013)

[12] Samsudin, A. ,Suhandi, A. Rusdiana, D. \& Kaniawati I.: Preliminary Design of ICI-based Multimedia for Reconceptualizing Electric Conceptions at UniversitasPendidikan Indonesia, Journal of Physics: Conference Series 739, 012006 (2016)

[13] Suwarna, I.P.: Analisis Miskonsepsi siswa SMA Kelas X pada Pelajaran Fisika Melalui CRI (Certai Respon Index) Termodifikasi. Jurnal laporan penelitian. Jakarta: Universitas negeri islam syarif hidayatullah. Retrieved from http://repository.uinjkt.ac.id/dspace /bitstream/123456789/24028/3/ (2013)

[14] Tekkaya C.: Misconceptions as Barrier to Understanding Biology. Journal of Universitas Hacettepe Ankara. pp. 23 (2002)

[15] Yerita, H. Haviz, M. \& Rahmi, E.: Efektivitas Penggunaan Modul Pembelajaran Biologi Berbasis Kontekstual Pada Pokok Bahasan Ekosistem Siswa Kelas X di SMAN 1 Rambatan. Edusainstika. pp .8-10. (2014)

[16] Zaleha. Samsudin, A. Nugraha, M.G.: Pengembangan Instrumen Tes Diagnostik VCCI Berbentuk Four-Tier Test Pada Konsep Getaran. Jurnal pendidikan fisika dan keilmuan (JPFK). Universitas pendidikan Indonesia. pp. 37-42 (2017) 